\title{
Penerapan Metode Stop Think Do Learning Untuk Meningkatkan Hasil Belajar Fisika pada Siswa Kelas Xb SMA Negeri 2 Dolo
}

\author{
Erlin, I Wayan Darmadi, dan Haeruddin
}

Email: Erlindahlusiyana@yahoo.co.id

Program Studi Pendidikan Fisika, Jurusan Pendidikan MIPA, Universitas Tadulako

Jl. Soekarno Hatta KM. 9 Kampus Bumi Tadulako Tondo Palu - Sulawesi Tengah

\begin{abstract}
Abstrak - Penelitian ini merupakan penelitian tindakan kelas yang bertujuan untuk meningkatkan hasil belajar fisika pada siswa SMA Negeri 2 Dolo dengan menerapkan metode Stop Think Do Learning di kelas XB. Desain penelitian ini mengikuti model Kemmis dan Mc. Taggart dengan subyek melibatkan 25 orang siswa. Materi penelitian untuk siklus I yaitu suhu dan pemuaian, dan untuk siklus II yaitu kalor dan perubahan wujud, dan perpindahan kalor. Data yang digunakan pada penelitian ini terdiri dari dua jenis yaitu, data kualitatif dan kuantitatif. Hasil penelitian pada siklus I didapatkan ketuntasan klasikal sebesar $72,00 \%$ dan daya serap klasikal $72,80 \%$, aktivitas guru berada pada kategori baik yaitu dengan persentase $80,00 \%$ dan aktivitas siswa berada pada kategori cukup yaitu dengan persentase $70,00 \%$. Pada siklus II ketuntasan belajar klasikal sebesar $92,00 \%$ dan daya serap klasikal sebesar $82,76 \%$, aktivitas guru berada pada kategori sangat baik dengan persentase $92,50 \%$ dan aktivitas siswa berada pada kategori sangat baik dengan persentase $91,25 \%$. Berdasarkan indikator kinerja, maka dapat disimpulkan bahwa penerapan metode Stop Think Do Learning dapat meningkatkan hasil belajar pada siswa kelas XB SMA Negeri 2 Dolo.
\end{abstract}

Kata Kunci: Metode Stop Think Do Learning; Hasil Belajar Fisika

\section{PENDAHULUAN}

Pendidikan pada dasarnya merupakan suatu proses untuk membantu manusia dalam mengembangkan dirinya, sehingga mampu menghadapi segala perubahan dan permasalahan dengan sikap terbuka serta pendekatan kreatif perlu adanya pendidikan yang dirancang dengan berbagai cara agar mendukung pencapaian pembentukan manusia yang diharapkan.

Berdasarkan hasil wawancara dengan guru fisika di SMA Negeri 2 Dolo pada tanggal 16 Februari 2013, masalah yang terjadi adalah kondisi pembelajaran fisika masih belum pelaksanaan pembelajaran fisika masih sering dilaksanakan dengan menggunakan metode konvensional (ceramah). Kegiatan pembelajaran dengan metode ceramah cenderung monoton berupa transfer pengetahuan dari guru ke siswa yang tidak terlalu menarik perhatian dan minat belajar siswa meskipun ada kesempatan bagi siswa untuk bertanya. Seseorang yang berminat terhadap suatu pelajaran akan cenderung bersungguh-sungguh dalam mempelajari pelajaran tersebut, sebaliknya seseorang yang kurang berminat terhadap suatu pelajaran akan cenderung enggan mempelajari pelajaran tersebut. Selain itu siswa kurang berinteraksi pada saat kegiatan pembelajaran membuat siswa kurang aktif dalam pembelajaran serta membuat siswa cepat bosan dan jenuh sehingga berimplikasi pada hasil belajar yang rendah. Akibatnya hasil belajar fisika siswa juga kurang memuaskan. Hal ini dapat dilihat dari hasil belajar siswa kelas X SMA Negeri 2 Dolo tahun ajaran 2012-2013 pada Tabel 1.

Tabel 1. Hasil Belajar Fisika Siswa Kelas X SMA Negeri 2 Dolo

\begin{tabular}{|c|c|c|}
\hline No & Kelas & Nilai rata-rata \\
\hline 1. & $\mathrm{X}_{\mathrm{A}}$ & 66,60 \\
\hline 2. & $\mathrm{X}_{\mathrm{B}}$ & 65,60 \\
\hline 3. & $\mathrm{X}_{\mathrm{C}}$ & 67,50 \\
\hline 4. & $\mathrm{X}_{\mathrm{D}}$ & 68,90 \\
\hline
\end{tabular}

Sumber: SMA Negeri 2 Dolo

Berdasarkan kondisi di atas, penulis termotivasi melakukan penelitian tindakan berupa peningkatan hasil belajar fisika melalui metode Stop Think Do Learning. Karena pada metode Stop Think Do Learning, siswa bisa menemukan sendiri dan mentransformasikan informasi komplek, mengecek informasi baru dengan aturan-aturan lama dan merevisinya (teori kontruktivisme) tetapi bisa juga menemukan sendiri dan mentransformasikan dengan bantuan guru. Metode ini dapat dikatakan metode setapak-demi setapak karena dalam pelaksanaannya ada langkah-langkah yang harus diperhatikan. Dengan metode Stop Think Do Learning diharapkan mampu meningkatkan hasil belajar siswa. 


\section{METODOLOGI PENELITIAN}

Penelitian ini merupakan penelitian tindakan kelas (PTK) yang dilakukan dalam dua siklus. Tiap siklus terdiri dari empat fase, yaitu: perencanaan tindakan, pelaksanaan tindakan, observasi, dan refleksi. Tahap penelitian ini mengacu pada alur PTK model Kurt Lewin yang dikembangkan oleh Kemmis dan Mc. Taggart.

Subyek penelitian ini adalah seluruh siswa kelas XB SMA Negeri 2 Dolo yang terdaftar pada tahun ajaran 2012/2013 yang berjumlah 25 orang siswa yang terdiri dari 12 orang siswa perempuan dan 13 orang siswa laki-laki. Data yang dikumpulkan dalam penelitian ini adalah hasil belajar siswa dalam mengerjakan soalsoal fisika yang diberikan melalui tes akhir setiap tindakan dan hasil observasi yang memuat catatan mengena kegitan pembelajaran, baik yang berkaitan dengan guru(peneliti) maupun yang berkaitan dengan siswa, serta hasil belajar siswa.

Teknik analisa data yang digunakan adalah data kuantitatif yang diperoleh dari hasil tes belajar siswa dan menentukan presentase ketuntasan belajar siswa. Indikator yang menunjukkan keberhasilan pembelajaran atau peningkatan hasil belajar siswa yaitu jika daya serap individu memperoleh nilai minimal 65\% dari skor ideal dan ketuntasan klasikal minimal $80 \%$. Indikator kualitatif pembelajaran dapat dilihat dari observasi aktivitas siswa dan aktivitas guru. Penelitian ini dinyatakan berhasil jika kualitas untuk aspek yang dinilai tersebut telah berada dalam kriteria baik atau sangat baik.

\section{HASIL DAN PEMBAHASAN}

\section{a. Siklus I}

\section{Pelaksanaan Tindakan Siklus I}

Pada pembelajaran siklus I dilakukan dengan membagi siswa dalam 5 kelompok, setiap kelompok terdiri dari 5 orang. Siswa dibagikan LKS untuk dikerjakan secara berkelompok, mendiskusikan dan mempresentasekan di depan kelas.

Pelaksanaan tindakan pada siklus I yang hendak dilaksanakan mengacu pada perencanaan tindakan siklus I yang terdiri dari skenario pembelajaran yang telah disusun kemudian penyajian materi suhu dan pemuaian yang dilaksanakan sebanyak 2 kali pertemuan, setiap kali pertemuan atau tatap muka dilakukan pengisian lembar observasi siswa dan
ISSN 23383240

guru oleh observer. Kemudian pada akhir pelaksanaan siklus dilakukan evaluasi terhadap siswa guna mengetahui hasil belajar atau kemampuan siswa.

\section{Analisis Hasil Observasi Aktivitas Guru dan Siswa Siklus I}

Hasil yang didapatkan dari pengamatan atau observasi yang dilakukan dalam kegiatan belajar mengajar pada setiap pertemuan pada siklus I adalah persentase aktivitas guru pada pertemuan 1 adalah $75,00 \%$, sedangkan pada pertemuan 2 adalah $85,00 \%$, dan persentase rata-rata adalah $80,00 \%$ berada pada kategori baik. Untuk persentase aktivitas siswa pada siklus I pertemuan 1 adalah $65,00 \%$, untuk pertemuan 2 adalah $75,00 \%$ sedangkan ratarata persentasenya $70,00 \%$ berada pada kategori cukup baik. Hal ini dapat dilihat dari grafik peningkatannya pada gambar berikut:

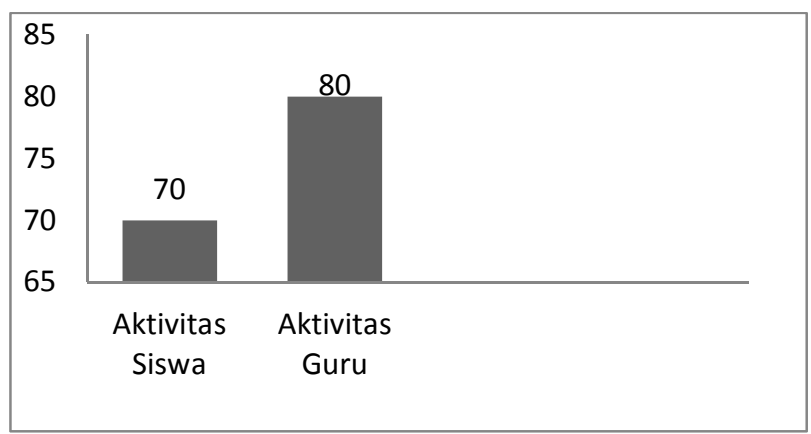

Gambar 1. Analisi Hasil Observasi Aktivitas Guru dan Siswa Siklus I

\section{Analisis Penilaian Sikap Siswa Siklus I}

Tabel 2. Persentase Penilaian sikap siswa pada siklus I.

\begin{tabular}{|c|c|c|c|c|c|}
\hline \multirow[b]{2}{*}{ No } & \multirow[b]{2}{*}{$\begin{array}{l}\text { Aspek Penilaian } \\
\text { Sikap }\end{array}$} & \multicolumn{2}{|c|}{ Pertemuan 1} & \multicolumn{2}{|c|}{ Pertemuan 2} \\
\hline & & $\begin{array}{c}\text { Skor } \\
\text { perole } \\
\text { han }\end{array}$ & $\begin{array}{c}\text { Keterc } \\
\text { apain } \\
(\%)\end{array}$ & $\begin{array}{c}\text { Skor } \\
\text { perole } \\
\text { han }\end{array}$ & $\begin{array}{c}\text { Keterc } \\
\text { apain } \\
(\%)\end{array}$ \\
\hline 1 & Kehadiran & 91 & 91,00 & 100 & 100 \\
\hline 2 & $\begin{array}{l}\text { Keaktifan dalam } \\
\text { KBM }\end{array}$ & 74 & 74,00 & 82 & 82,00 \\
\hline 3 & $\begin{array}{l}\text { Perhatian } \\
\text { mengikuti } \\
\text { pelajaran }\end{array}$ & 72 & 72,00 & 90 & 90,00 \\
\hline 4 & $\begin{array}{l}\text { Keaktifan dalam } \\
\text { mencari jawaban }\end{array}$ & 83 & 83,00 & 81 & 81,00 \\
\hline \multicolumn{2}{|r|}{ Jumlah Skor } & \multicolumn{2}{|c|}{322} & \multicolumn{2}{|c|}{353} \\
\hline \multicolumn{2}{|r|}{ Keberhasilan (\%) } & \multicolumn{2}{|c|}{80,50} & \multicolumn{2}{|c|}{88,25} \\
\hline & Kategori & \multicolumn{2}{|c|}{ Baik } & \multicolumn{2}{|c|}{ Baik } \\
\hline
\end{tabular}

Berdasarkan Tabel II memperlihatkan bahwa aspek-aspek sikap siswa yang diamati dalam kegiatan belajar-mengajar berada pada kategori baik. Hal ini dapat dilihat dari grafik peningkatannya pada gambar 2 . 


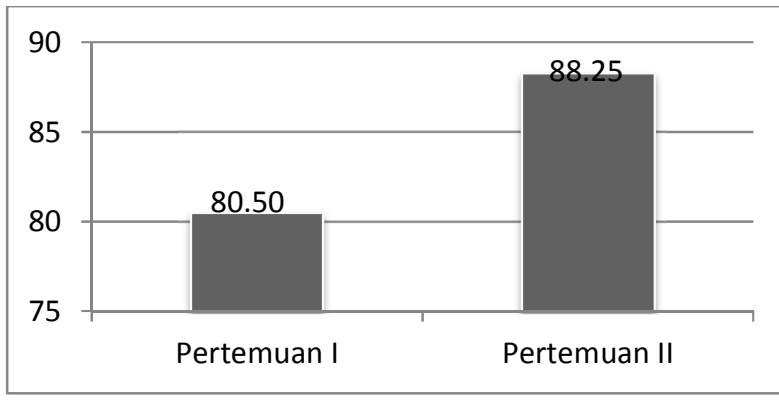

Gambar 2. Analisis Penilaian Sikap Siswa Siklus I

\section{Analisis Penilaian Kelompok Siklus I}

Kegiatan pada siklus I, selain penilaian secara individu juga dilakukan secara kelompok. Persentase penilaian kelompok dapat dilihat pada tabel berikut :

Tabel 3. Analisis Penilaian Kelompok Siklus I

\begin{tabular}{|c|c|c|c|c|c|}
\hline \multirow[b]{2}{*}{ No } & \multirow[b]{2}{*}{ Aspek Penilaian Sikap } & \multicolumn{2}{|c|}{ Pertemuan 1} & \multicolumn{2}{|c|}{ Pertemuan 2} \\
\hline & & $\begin{array}{c}\text { Skor } \\
\text { pero } \\
\text { leha } \\
n\end{array}$ & $\begin{array}{c}\text { Keterc } \\
\text { apain } \\
(\%)\end{array}$ & $\begin{array}{c}\text { Skor } \\
\text { pero } \\
\text { leha } \\
n\end{array}$ & $\begin{array}{c}\text { Keterc } \\
\text { apain } \\
(\%)\end{array}$ \\
\hline 1 & $\begin{array}{l}\text { Keterampilan melakukan } \\
\text { pengamatan }\end{array}$ & 63 & 63,00 & 75 & 75,00 \\
\hline 2 & $\begin{array}{l}\text { Keterampilan menyusun } \\
\text { alat dan bahan }\end{array}$ & 67 & 67,00 & 76 & 76,00 \\
\hline 3 & $\begin{array}{l}\text { Keterampilan mengisi } \\
\text { LKS }\end{array}$ & 65 & 65,00 & 71 & 71,00 \\
\hline 4 & $\begin{array}{l}\text { Keterampilan } \\
\text { menyimpulkan/ } \\
\text { mengkomunikasikan }\end{array}$ & 55 & 55,00 & 64 & 64,00 \\
\hline 5 & Kekompakan kelompok & 67 & 67,00 & 81 & 81,00 \\
\hline 6 & Saling menghargai & 62 & 62,00 & 73 & 73,00 \\
\hline & Jumlah Skor & \multicolumn{2}{|c|}{379} & 440 & \\
\hline & Keberhasilan (\%) & \multicolumn{2}{|c|}{63,17} & \multicolumn{2}{|c|}{73,33} \\
\hline & Kategori & & ang & \multicolumn{2}{|c|}{ Cukup } \\
\hline
\end{tabular}

Berdasarkan Tabel III memperlihatkan bahwa penilaian untuk masing-masing kelompok yang diamati selama kegiatan belajar mengajar (KBM). Hal ini dapat dilihat dari grafik peningkatannya pada gambar berikut:

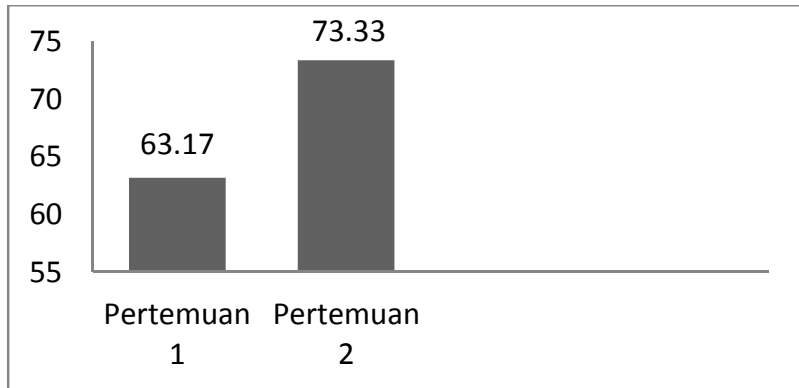

Gambar 3. Analisis Penilaian Kelompok Siklus I
5. Analisis Hasil Belajar Fisika

Tabel 4. Hasil Analisis Belajar Fisika

\begin{tabular}{|c|l|c|}
\hline No & \multicolumn{1}{|c|}{ Aspek Perolehan } & Hasil \\
\hline 1. & Skor tertinggi & 90.00 \\
\hline 2. & Skor terendah & 55.00 \\
\hline 3. & Banyaknya siswa yang tuntas & 18 orang \\
\hline 4. & $\begin{array}{l}\text { Banyaknya siswa yang tidak } \\
\text { tuntas }\end{array}$ & 7 orang \\
\hline 5. & Persentase ketuntasan klasikal & $72.00 \%$ \\
\hline 6. & Persentase daya serap klasikal & $72.80 \%$ \\
\hline
\end{tabular}

Tabel di atas menunjukan bahwa analisis tes akhir belajar fisika siswa kelas $X_{B}$ menunjukkan skor tertinggi dengan hasil 90,00 berjumlah 4 orang dan skor terendah 55,00 berjumlah 1 orang. Hal ini dapat dilihat dari grafik peningkatannya pada gambar berikut :

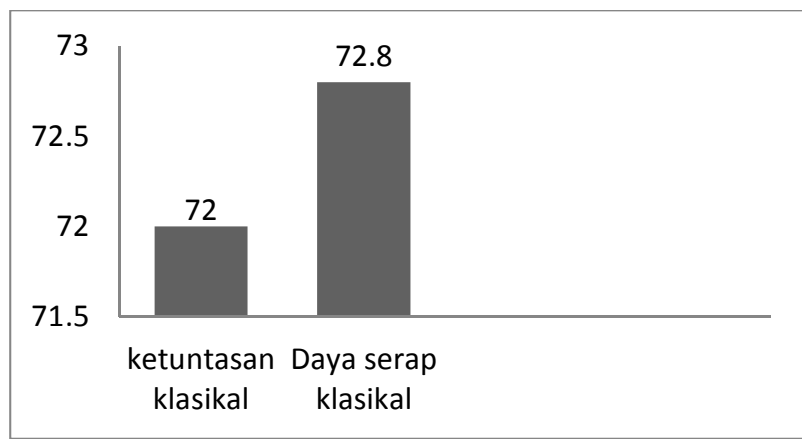

Gambar 4. Analisis Hasil Belajar Fisika

\section{Refleksi Tindakan}

Refleksi tindakan dilakukan guru guna mencari kekurangan dari pembelajaran siklus I, dan merekomendasikan kekurangan untuk diperbaiki pada siklus II. Adapun kekurangan pada siklus I adalah siswa belum seluruhnya siap menerima materi, Sebagian siswa belum sepenuhnya mampu memahami dan memikirkan permasalahan/pertanyaan dari guru, Sebagian siswa masih ada yang raguragu untuk bertanya terkait dengan materi yang dibahas. Selain itu sebagian siswa masih malu dan ragu dalam mengeluarkan pendapatnya dalam diskusi kelompok dan masih takut bertanya mengenai materi yang belum dipahami serta masih ada kelompok yang belum menyelesaikan kuis jigsaw puzzle tepat pada waktunya. Untuk mengatasi masalah tersebut, maka rekomendasi yang dilakukan peneliti adalah memberikan arahan agar siswa siap mengikuti kegiatan pembelajaran, peneliti lebih akrab lagi dengan siswa dan memberikan kesempatan bertanya 
kepada siswa dengan intensitas yang lebih banyak dari pertemuan sebelumnya pada saat proses pembelajaran. Membimbing siswa bekerjasama dan saling tukar pendapat dalam kelompoknya, karena dengan adanya kerja sama, saling tukar pendapat dan saling berinteraksi dalam kelompok menuntut siswa saling menghargai pendapat dan berdiskusi untuk menyelesaikan pemecahan masalah atau tugas yang diberikan oleh guru.

Tabel 5. Refleksi Tindakan

\begin{tabular}{|c|c|c|c|c|c|}
\hline \multirow[b]{2}{*}{ No } & \multirow[b]{2}{*}{$\begin{array}{l}\text { Aspek Penilaian } \\
\text { Sikap }\end{array}$} & \multicolumn{2}{|c|}{ Pertemuan 1} & \multicolumn{2}{|c|}{ Pertemuan 2} \\
\hline & & $\begin{array}{l}\text { Skor } \\
\text { perol } \\
\text { ehan }\end{array}$ & $\begin{array}{c}\text { Keter } \\
\text { capai } \\
\text { n (\%) }\end{array}$ & $\begin{array}{l}\text { Skor } \\
\text { perol } \\
\text { ehan }\end{array}$ & $\begin{array}{l}\text { Keter } \\
\text { capai } \\
\mathrm{n}(\%) \\
\end{array}$ \\
\hline 1 & Kehadiran & 100 & 100 & 100 & 100 \\
\hline 2 & $\begin{array}{l}\text { Keaktifan dalam } \\
\text { KBM }\end{array}$ & 85 & 85,00 & 92 & 92,00 \\
\hline 3 & $\begin{array}{l}\text { Perhatian } \\
\text { mengikuti } \\
\text { pelajaran }\end{array}$ & 96 & 96,00 & 98 & 98,00 \\
\hline 4 & $\begin{array}{l}\text { Keaktifan dalam } \\
\text { mencari jawaban }\end{array}$ & 88 & 88,00 & 92 & 92,00 \\
\hline \multicolumn{2}{|r|}{ Jumlah Skor } & \multicolumn{2}{|c|}{369} & \multicolumn{2}{|c|}{381} \\
\hline \multicolumn{2}{|r|}{ Keberhasilan (\%) } & \multicolumn{2}{|c|}{92,25} & \multicolumn{2}{|c|}{95,25} \\
\hline \multicolumn{2}{|r|}{ Kategori } & \multicolumn{2}{|c|}{ Sangat Baik } & \multicolumn{2}{|c|}{ Sangat Baik } \\
\hline
\end{tabular}

\section{b. Siklus II}

\section{Pelaksanaan Tindakan Siklus II}

Pada dasarnya kegiatan yang dilakukan pada siklus II sama dengan kegiatan yang dilakukan pada siklus I.

2. Analisis Hasil Observasi Aktivitas Guru dan Siswa Siklus II

Hasil yang didapatkan dari pengamatan atau observasi yang dilakukan dalam kegiatan belajar mengajar pada setiap pertemuan pada siklus II adalah persentase aktivitas guru pada pertemuan 1 adalah $90,00 \%$, sedangkan pada pertemuan 2 adalah 95,00\%, dan persentase rata-rata adalah $92,50 \%$ berada pada kategori sangat baik. Untuk persentase aktivitas siswa pada siklus II pertemuan 1 adalah $87,50 \%$, untuk pertemuan 2 adalah 95,00\% sedangkan rata-rata persentasenya $91,25 \%$ berada pada kategori sangat baik. Hal ini dapat dilihat dari grafik peningkatannya pada gambar berikut:

ISSN 23383240

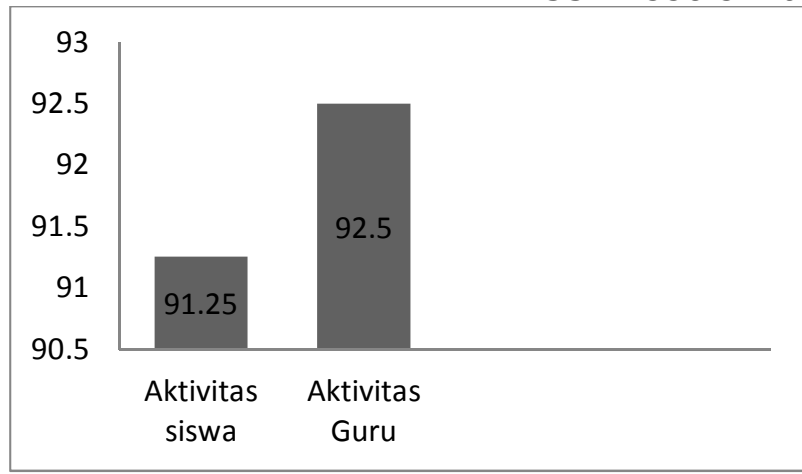

Gambar 5. Refleksi Tindakan

\section{Analisis Penilaian Sikap Siswa Siklus II}

Persentase Penilaian sikap siswa pada siklus II dapat dilihat pada tabel berikut:

Berdasarkan tabel persentase memperlihatkan bahwa aspek-aspek sikap siswa yang diamati dalam kegiatan belajarmengajar berada pada kategori sangat baik. $\mathrm{Hal}$ ini dapat dilihat dari grafik peningkatannya pada gambar berikut :

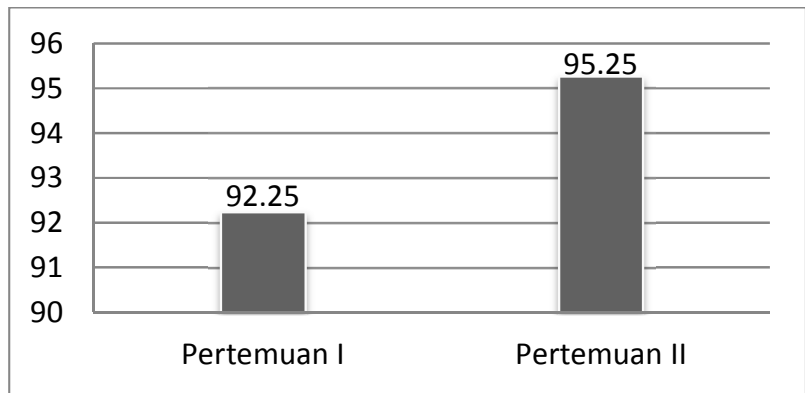

Gambar 6. Analisis Penilaian Sikap SIswa Siklus II

\section{Analisis Penilaian Kelompok Siklus II}

Kegiatan pada siklus II, selain penilaian secara individu juga dilakukan secara kelompok. Persentase penilaian kelompok dapat dilihat pada tabel berikut: 
Berdasarkan tabel di atas memperlihatkan bahwa penilaian untuk masing-masing kelompok yang diamati selama kegiatan belajar mengajar (KBM). Hal ini dapat dilihat dari grafik peningkatannya pada gambar 6 .

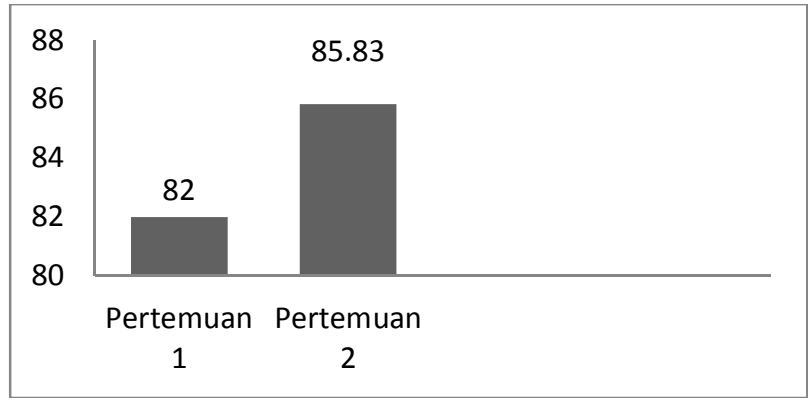

Gambar 6. Analisis Penilaian Kelompok Siklus II

\section{Analisis Hasil Belajar Fisika}

Hasil analisis tes dapat dilihat pada tabel berikut:

Tabel 6. Analisis Hasil Belajar Fisika

\begin{tabular}{|c|l|c|}
\hline No & \multicolumn{1}{|c|}{ Aspek Perolehan } & Hasil \\
\hline 1. & Skor tertinggi & 100.00 \\
\hline 2. & Skor terendah & 65.00 \\
\hline 3. & Banyaknya siswa yang tuntas & 23 \\
\hline 4. & Banyaknya siswa yang tidak tuntas & 2 \\
\hline 5. & Persentase ketuntasan klasikal & 92.00 \\
\hline 6. & Persentase daya serap klasikal & 82.76 \\
\hline
\end{tabular}

Hasil tes akhir tindakan siklus II terlihat bahwa adanya peningkatan ketuntasan klasikal dibandingkan pada siklus sebelumnya, sedangkan daya serap klasikal juga mengalami peningkatan dari siklus sebelumnya. Hal ini dapat dilihat dari grafik peningkatannya pada gambar berikut:

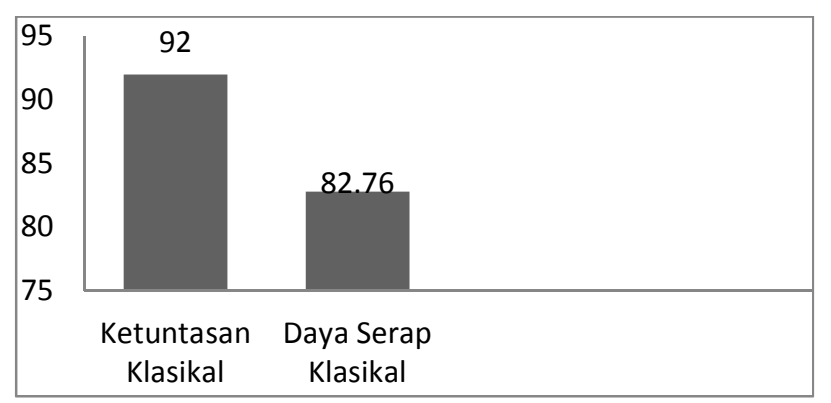

Gambar 7. Analisis Hasil Belajar Fisika
ISSN 23383240

\begin{tabular}{|c|c|c|c|c|c|}
\hline \multirow[b]{2}{*}{ No } & \multirow[b]{2}{*}{$\begin{array}{c}\text { Aspek Penilaian } \\
\text { Sikap }\end{array}$} & \multicolumn{2}{|c|}{ Pertemuan 1} & \multicolumn{2}{|c|}{ Pertemuan 2} \\
\hline & & $\begin{array}{c}\text { Skor } \\
\text { perole } \\
\text { han }\end{array}$ & $\begin{array}{l}\text { Keterca } \\
\text { pain } \\
(\%)\end{array}$ & $\begin{array}{l}\text { Skor } \\
\text { perole } \\
\text { han }\end{array}$ & $\begin{array}{c}\text { Keterc } \\
\text { apain } \\
(\%)\end{array}$ \\
\hline 1 & $\begin{array}{l}\text { Keterampilan } \\
\text { melakukan } \\
\text { pengamatan }\end{array}$ & 84 & 84,00 & 85 & 85,00 \\
\hline 2 & $\begin{array}{l}\text { Keterampilan } \\
\text { menyusun alat dan } \\
\text { bahan }\end{array}$ & 83 & 83,00 & 88 & 88,00 \\
\hline 3 & $\begin{array}{l}\text { Keterampilan } \\
\text { mengisi LKS }\end{array}$ & 80 & 80,00 & 90 & 90,00 \\
\hline 4 & $\begin{array}{l}\text { Keterampilan } \\
\text { menyimpulkan/ } \\
\text { mengkomunikasikan }\end{array}$ & 75 & 75,00 & 75 & 75,00 \\
\hline 5 & $\begin{array}{l}\text { Kekompakan } \\
\text { kelompok }\end{array}$ & 87 & 87,00 & 89 & 89,00 \\
\hline 6 & Saling menghargai & 85 & 85,00 & 90 & 90,00 \\
\hline & Jumlah Skor & \multicolumn{2}{|c|}{492} & \multicolumn{2}{|c|}{515} \\
\hline & Keberhasilan (\%) & \multicolumn{2}{|c|}{82,00} & \multicolumn{2}{|c|}{85,83} \\
\hline & Kategori & \multicolumn{2}{|c|}{ Baik } & \multicolumn{2}{|c|}{ Baik } \\
\hline
\end{tabular}

Berdasarkan observasi guru selama kegiatan pembelajaran tiap siklus, dimana persentase aktivitas guru pada siklus I sebesar $80,00 \%$ dan siklus II sebesar 92,50\% disini terjadi peningkatan aktivitas guru sebesar $12,50 \%$. Sedangkan untuk observasi siswa selama kegiatan pembelajaran tiap siklus, dimana persentase aktivitas siswa pada siklus I sebesar $70,00 \%$ dan pada siklus II sebesar 91,25\% disini terjadi peningkatan aktivitas siswa sebesar 21,25\%. Ini disebabkan karena kekurangan-kekurangan pada siklus I dapat diminimalisir dan diperbaiki pada siklus II.

Adapun kekurangan pada siklus I adalah siswa belum seluruhnya siap menerima materi, sebagian siswa belum sepenuhnya mampu memahami materi yang diterimanya dan sebagian siswa belum sepenuhnya mampu memahami dan memikirkan permasalahan/pertanyaan dari guru, serta masih banyak siswa yang kurang aktif dalam pemecahan masalah ketika proses diskusi kelompok, sebagian siswa tidak membuat catatan-catatan dari hasil demonstrasi dan siswa kurang bisa menyelesaikan tugas dengan baik. Selain itu sebagian siswa masih malu dan ragu dalam mengeluarkan pendapatnya dalam diskusi kelompok dan masih takut bertanya mengenai materi yang belum dipahami serta masih ada kelompok yang belum menyelesaikan kuis tepat pada waktunya. Untuk mengatasi masalah tersebut, maka rekomendasi yang dilakukan peneliti adalah memberikan arahan agar siswa siap mengikuti kegiatan pembelajaran, peneliti lebih akrab lagi dengan siswa dan memberikan kesempatan bertanya kepada siswa dengan intensitas yang lebih banyak dari pertemuan sebelumnya pada saat proses pembelajaran. Membimbing siswa bekerjasama dan saling tukar pendapat dalam kelompoknya, karena dengan adanya 
kerjasama, saling tukar pendapat dan saling berinteraksi dalam kelompok menuntut siswa saling menghargai pendapat dan berdiskusi untuk menyelesaikan pemecahan masalah atau tugas yang diberikan oleh guru. Sehingga siswa bisa lebih mudah menyelesaikan pemecahan masalah dan tugas yang diberikan oleh guru tersebut.

Selain peningkatan pada aktivitas siswa dan guru, terjadi pula peningkatan pada sikap siswa dan kinerja siswa. Hal ini dapat dilihat dari hasil perolehan persen ketercapaian sikap siswa pada siklus I berada pada kategori baik sedangkan pada siklus II sikap siswa berada pada kategori sangat baik dan untuk kinerja siswa pada siklus I persen ketercapaian berada pada kategori kurang dan cukup sedangkan pada siklus II berada pada kategori baik. Peningkatan tersebut dikarenakan guru (peneliti) berusaha untuk meminimalisir kekurangan-kekurangan yang terjadi pada siklus I dan melakukan perbaikan berdasarkan rekomendasi. Peneliti berusaha memberikan arahan agar siswa siap mengikuti kegiatan pembelajaran, membimbing siswa dalam pembentukan kelompok serta adanya kerjasama, saling berinteraksi dan saling tukar pendapat, menuntut mereka saling menghargai pendapat dan berdiskusi untuk menyelesaikan pertanyaan pada lembar kerja siswa yang diberikan oleh guru.

Berdasarkan hasil penelitian yang dilakukan, dengan metode Stop Think Do Learning yang digunakan merupakan salah satu alternatif untuk meningkatkan hasil belajar fisika. Pada siklus I dan siklus II terjadi peningkatan hasil belajar, hal ini terlihat dari ketuntasan klasikal yang diperoleh pada siklus I yaitu $72,00 \%$ dimana masih terdapat 7 orang siswa yang belum tuntas sedangkan ketuntasan klasikal pada siklus II yaitu 92,00\% dimana terdapat 2 orang siswa yang belum tuntas, yang berarti terjadi peningkatan ketuntasan klasikal sebesar $27,78 \%$. Selain itu, diketahui pula bahwa peningkatan daya serap klasikal dari siklus I ke siklus II, dimana daya serap klasikal pada siklus I sebesar $72,80 \%$ dan daya serap klasikal pada siklus II sebesar $82,76 \%$. Hal tersebut berarti terjadi peningkatan daya serap klasikal sebesar $13,68 \%$.

Adapun penyebab masih belum tercapainya standar ketuntasan klasikal dan standar ketuntasan daya serap klasikal pada siklus I disebabkan pada saat proses pembelajaran di kelas pada siklus I masih didapatkan beberapa
ISSN 23383240

kelemahan, diantaranya masih terdapat sebagian siswa yang belum siap menerima materi serta kerjasama anatara anggota kelompok masih kurang. Selain itu penyampaian materi yang diberikan masih belum dapat dipahami dengan baik oleh siswa. Sehingga pada siklus I, masih ada siswa yang belum dapat mengerjakan dengan baik soal-soal yang diberikan khususnya dalam mengerjakan tes dalam bentuk perhitungan. Hal ini disebabkan siswa tersebut cenderung diam (tidak bertanya) saat ada materi yang kurang dipahaminya saat KBM berlangsung, sehingga kesulitan dalam menyelesaikan soal, tidak memperhatikan dengan baik materi yang disampaikan, serta tidak belajar untuk persiapan ujian. Ketika siswa diberikan tugas untuk melakukan kegiatan diskusi secara kelompok, maka siswa akan melakukan interaksi seperti berkomunikasi, mengeluarkan pendapat dan mendengarkan pendapat, sehingga siswa akan menyadari bahwa mereka akan belajar dengan baik ketika mereka saling bekerja sama.

\section{KESIMPULAN DAN SARAN}

Berdasarkan hasil analisa data dan pembahasan pada penelitian ini, maka dapat disimpulkan bahwa penerapan metode Stop Think Do Learning dapat meningkatkan hasil belajar Fisika pada siswa kelas X B SMA Negeri 2 Dolo. Untuk hasil belajar siklus I diperoleh nilai ketuntasan belajar klasikal sebesar $72,00 \%$ dan daya serap klasikal $72,80 \%$. Sedangkan pada siklus II diperoleh nilai ketuntasan belajar klasikal sebesar $92,00 \%$ dan daya serap klasikal $82,76 \%$ yang artinya sudah melewati standar ketuntasan klasikal siswa yang dipersyaratkan. Untuk hasil observasi aktivitas siswa dan guru pada siklus I berada pada kategori cukup dan baik, sedangkan pada siklus II berada pada kategori sangat baik.Saran peneliti kepada guru maupun calon guru yang ingin menerapkan metode Stop Think Do Learning disarankan memperhatikan beberapa hal yaitu: harus lebih memperhatikan dan mengefektifkan waktu selama pembelajaran dan menciptakan suasana keakraban antara guru dengan siswa, tidak membuat jarak antara keduanya, menumbuhkan rasa percaya diri siswa, memberikan perhatian dan motivasi untuk senantiasa menjaga kerja sama dalam kelompok. 


\section{DAFTAR PUSTAKA}

[1] Depdiknas, (2003). Penelitian Tindakan Kelas. Jakarta: Departemen Pendidikan Nasional.

[2] Tim Penyusun. (2013). Pedoman Penyusunan dan Penilaian Karya Ilmiah. Palu: FKIP UNTAD.

[3] Petersen, L, (2004). Bagaimana Memotivasi Anak Belajar Stop and Think Learning. Jakarta: PT Gramedia.

[4] Sudjana,N. (1989). Dasar-Dasar Proses Belajar Mengajar. Bandung: Sinar Baru Algensindo. 